\title{
Hanford Waste Vitrification Plant Capacity Increase Options
}

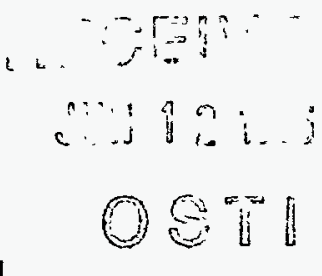

D. E. Larson

April 1996

Prepared for

the U.S. Department of Energy under Contract DE-AC06-76RLO 1830

Pacific Northwest National Laboratory Richland, Washington 99352 


\title{
Hanford Waste Vitrification Plant Capacity Increase Options
}

\author{
DE Larson
}

April 1996

Prepared for

the U.S. Department of Energy

under Contract DE-AC06-76RLO 1830

Pacific Northwest National Laboratory

Richland, Washington 99352 


\title{
DISCLAIMER
}

This report was prepared as an account of work sponsored by an agency of the United States Government. Neither the United States Government nor any agency thereof, nor Battelle Memorial Institute, nor any of their employees, makes any warranty, express or implied, or assumes any legal liability or responsibility for the accuracy, completeness, or.usefulness of any information, apparatus, product, or process disclosed, or represents that its use would not infringe privately owned rights. Reference herein to any specific commercial product, process, or service by trade name, trademark, manufacturer, or othenwise dues not necessarily constitute or imply its endorsement, recommendation, or favoring by the United States Government or any agency thereof, or Battelle Memorial institute. The views and opinions of authors expressed herein do not necessarily state or reflect those of the United States Government or any agency thereof.

\author{
PACIFIC NORTHWEST NATIONAL LABORATORY \\ operated by \\ BATTELLE \\ for the \\ UNITED STATES DEPARTMENT OF ENERGY \\ under Contract DE-AC06-76RLO 1830
}

\author{
Printed in the United States of America \\ Available to DOE and DOE contractors from the

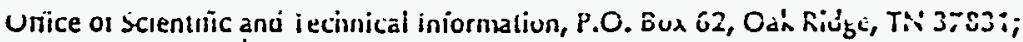 \\ prices available from (615) $576-8401$.
}

Available to the public from the National Technical Information Service,

U.S. Department of Commerce, 5285 Port Royal Rd., Springfield, VA 22161 


\section{CONTENTS}

1.0 INTRODUCTION

2.0 OBJECTIVES $\quad$. 2

3.0 CONCLUSIONS AND RECOMMENDATIONS 3

4.0 STUDY BASES

$\begin{array}{lll}5.0 & \text { PROCESS MODIFICATIONS OPTIONS } & 6\end{array}$

5.1 SIMPLIFIED HIGH CAPACITY FLOWSHEET DESCRIPTION $\quad$ i 6

5.2 MAJOR CHANGES TO CURRENT FLOHSHEET 9

5.3 PROCESS TIME CYCLE ANALYSES 11

5.4 ADDITIONAL OPTIONS ANALYSES 18

6.0 FACILITY AND EQUIPMENT IMPACTS 21

7.0 DEVELOPMENT REQUIREMENTS . . 24

8.0 ALTERNATIVE EVALUATION 26

$\begin{array}{lll}9.0 & \text { REFERENCES } & 33\end{array}$

APPENDICES:
A. CURRENT FLOHSHEET DESCRIPTION AND TIME CYCLES
A.1- A.5
B. APPLICABLE GERMAN VITRIFICATION TECHNOLOGY STATUS
B. 1 - B.3
C. CALCULATIONS
C.1 - C.6 


\subsection{INTRODUCTION}

Studies are being conducted by the Hanford Waste Vitrification Plant (HWVP) Project on ways to increase the waste processing capacity within the current Vitrification Building structural design. The Phase 1 study (Shah, 1993) on remote systems concepts identification and extent of capacity increase was completed. The study concluded that the HWVP capacity could be increased to four times the current capacity with minor design adjustments to the fixed facility design, and the required design changes would not impact the current "footprint" of the Vitrification Building. A further increase in production capacity may be achievable but would require some technology development, verification testing, and a more systematic and extensive engineering evaluation. The primary changes included a single advanced melter with a higher capacity (stirred or high temperature melter), new evaporative feed tank, offgas quench collection tank, ejector venturi scrubbers, an additional inner canister closure station, a smear test station, a new closecoupled analytical facility, waste hold capacity of $400,000 \mathrm{gal}$, the ability to concentrate out-of-plant HWVP feed to $90-\mathrm{g} / \mathrm{L}$ waste oxide concentration; and limited changes to the current base slab construction package (primarily incell service embeds and floor supports for the modified equipirent).

To complement these studies, Pacific Northwest Laboratory (PNL) has considered simplified HWVP processes and design modifications that could achieve major waste processing capacity increases within the current structural design of the Vitrification Building. This report identifies, describes, and contains a preliminary evaluation of such modifications. The results are relevant to and available to support the capacity increase studies being performed by the hiWV Project Phase II studies. 


\subsection{OBJECTIVES}

The objective of this study is to identify vitrification process improvements that can, with reasonable economy, substantially increase the HWVP waste processing capacity using the current structural design (i.e., "footprint") of the Vitrification Building.

The primary difference between this study and the Phase I study (Shah, 1993) is the bases used. This study allows the use of technological innovations on other processes and equipment equivalent to employing a modified meiter concept such as the stirred melter or the high temperature melter. Only process and equipment technologies are considered which are demonstrated or which require only modest verification testing/development. The ability must exist to implement these technologies within the time it would take to implement an advanced melter in the HWVP. Key special and service requirements of these technologies such as in-bed piping need to be identified for initial HWVP construction to facilitate implementation of the modifications with minimal facility impact. 


\subsection{CONCLUSIONS AND RECOMMENDATIONS}

The following conclusions and recommendations are a result of this study.

CONCLUSIONS:

- The HWVP glass processing capacity may be substantially increased within the existing "footprint" of the HWVP by reasonable extensions of existing technologies which could take up to five years to develop and implement. The approaches considered are indicated in the RECOMMENDATIONS.

- Implementing the simplified high capacity flowsheet will significantly enhance process performance and increase plant feed preparation capacity.

- Impacts of capacity increase on related HWVP operations not addressed in this study include waste/effluent handling, analytical support, canister handling and services which need to be addressed further. The conclusions from the Phase 1 study (Shah, 1993) may apply to results of this study.

RECOMMENDATIONS:

- Within study guidelines, the following HWVP modifications should be considered for implementation in the order indicated to significantly increase HWVP capacity.

- Install advanced high capacity melter (high temperature stirred)

- Maximize HWVP feed concentration received in plant $(90 \mathrm{~g} / 1$ of wO used in this study and is included in Phase I study) and perform process waste recycle concentration in SRAT or SHE as appropriate to minimize overall time cycle.

- Implement simplified high capacity flowsheet using an alternative reductant and direct process frit (dry) addition to the meiter.

- Maximize HWVP feed processing slurry concentrations

These combined changes could conceptually increase the HWVP capacity to over $500 \mathrm{~kg} / \mathrm{h}$ of glass, not including idle times. 
- Alternatively, if the HWVP feed concentration cannot be increased adequately, the heat transfer area in the SRAT/SME/DWTT can be significantly increased by converting the cooling coils to heating duty and placing cooling jackets on the tanks. The incentive to perform waste recycle concentration in the SRAT may not exist. This heat transfer modification for capacity increase should beneficial under any circumstances if foaming and/or entrainment are not rate limiting. If the $\mathrm{plant}$ feed concentration cannot be increased significantly, the glass production capacity can conceptualiy be increased to about 500 $\mathrm{kg} / \mathrm{h}$ without idle time by implementing this modification with the others.

- Increasing the batch sizes to the maximum by reducing the heel appears attractive in terms of capacity increase for the minor effort involved, included in Phase II study.

- Performing the SRAT and SME processes in one tank to enable operation of . two parallel feed preparation systems (one in SRAT and one in SME) increases processing capacity. This is included in the Phase II study together with adding a third SRAT/SME vessel for further parallel operations. 


\subsection{STUDY BASES}

The bases used for this study are as follows:

- The current design "footprint" of the HWVP Vitrification Building will not change.

- Technology changes will only be considered that are modest extensions of existing technologies and require limited development (i.e. can be readily implemented in the HWVP with a five year delay from 1999 with modest development funding).

- The current HWVP facility, equipment, and process desigh will be used to the maximum extent practicable and economical.

- The HWVP waste processing capacity will be maximized.

- Complementary bases and suppositions used for the Phase 1 studies (Shah, 1993) are appropriate for this study.

- Reference Flowsheet - Time/Motion Diagram: Fluor Daniel, Inc., No Date, "Time/Motion Diagram, Feed Receipt, Feed Preparation, Meiter Feed, Radioactive Process Waste Collection System, 220 1b/hr Glass Production, " H-2-12304I, 2 Sheets is used as the basis for this study although not fully current. This reference was used as the bases for the previous capacity increase study (Shah, 1993). Use of this bases facilitates compatibility of study results. 


\subsection{PROCESS HODIFICATIONS OPTIONS}

The simplified high capacity flowsheet is described in this section. A feed preparation process time-cycie is also presented and analyzed for flowsheet evaluation and comparison with the current reference and Phase 1 study time cycles. Some additional process modifications which may be. beneficially added to HWVP are discussed. A process flow diagram of the simplified high capacity flowsheet is shown in Figure 1.

\subsection{SIMPLIFIED HIGH CAPACITY FLOWSHEET DESCRIPTION}

The NCAW is pumped from the tank farm to the Slurry Receipt and Adjustment Tank (SRAT). The pumping rate is maximum until the tank is filled to the operating level. Tank heating for boiling is initiated as soon as the coils are covered, and heating is continued to achieve and maintain a maximum boil off rate with acceptable de-entrainment (assume $10 \mathrm{gpm}$ water boil off rate). The waste receipt rate in the tank is decreased to match the boil off rate and maintain the tani operating level. Waste receipt and concentration continues until the total amount of waste is received and the desired concentration is reached. The waste is then cooled to transfer temperature, sampled if deemed necessary (assumed no sampling for this study), and transferred to the SME.

Before the process waste addition, the SME contents are heated and concentration initiated to provide tank space for the waste recycle and obtain the final desired concentration. In the SME, the desired amount of canister decontamination waste containing Decontamination Waste Treatment Tank (DWTT) concentrated waste and treated waste recycle is added to the concentrated HWVP feed. On obtaining the final desired waste concentration and contents cooling, a sample can be taken to determine the reductant addition requirements and waste composition (assumed for time cycle analyses); or reductant requirements and waste composition can be deterimined from individual tank content analyses prior to transfer to the SME eliminating the need to wait for SME sample analyses, or reductant requirements and waste composition 


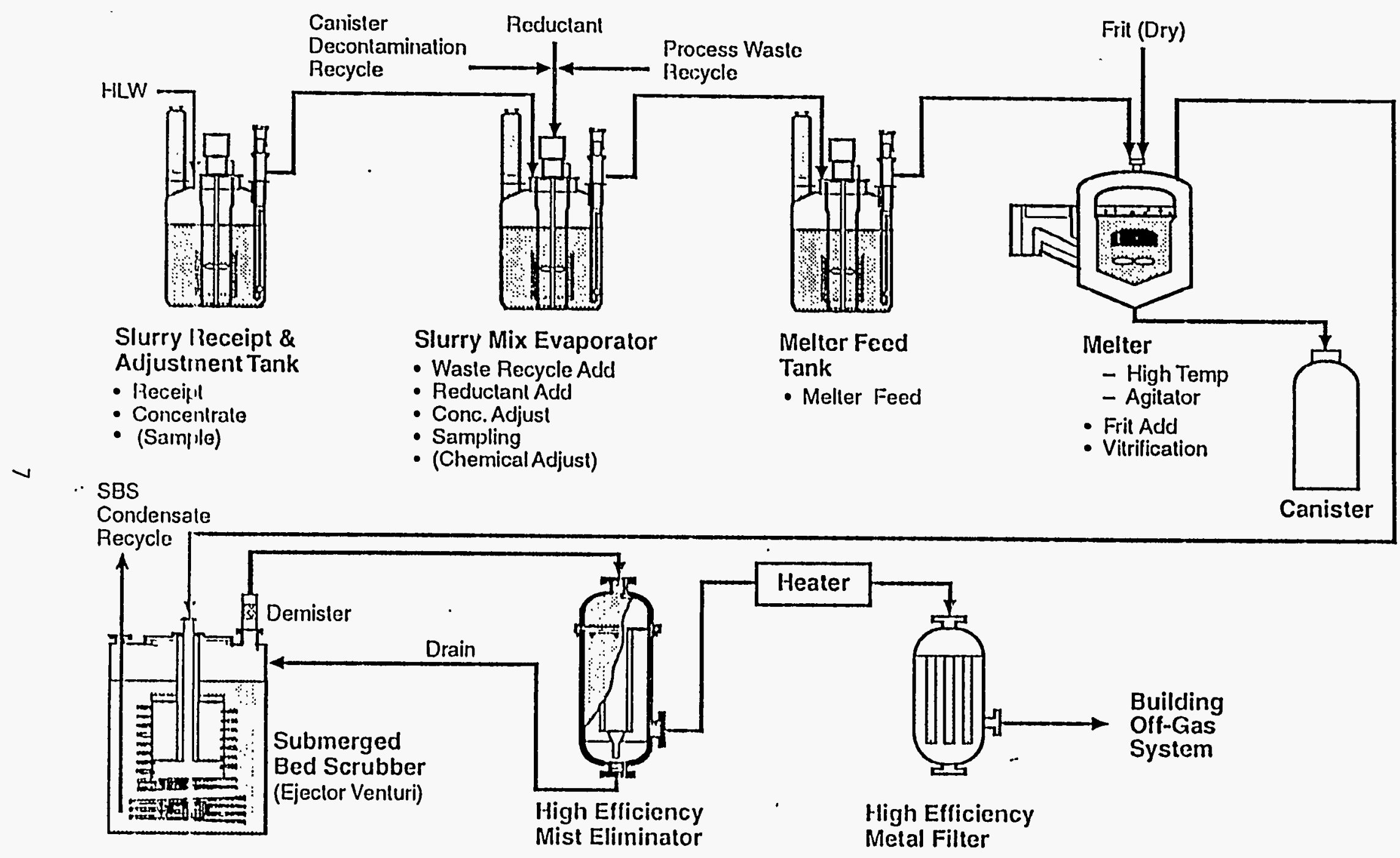

Figure 1. Hanford Waste Vitrification Plant Simplified High Capacity
Process Flow Diagram 
can be determined from previous experience with each stream added and periodic sampling eliminating the need to wait for SME sample analyses. The reductant is then added. The mixed waste may then be sampled to determine that the correct reductant adjustments have been made (this is assumed unnecessary in this study and not included in the time cycle analyses). The SME contents are then transferred to the Melter Feed Tank (MFT).

From the MFT, feed is pumped to the melter. No samples are needed from this tank except if needed for archive or waste form qualification.

In the meiter, dry frit is added in an appropriate ratip to the melter feed to form an acceptable glass. The melter is stirred and operated at a temperature up to $1500^{\circ} \mathrm{C}$ to increase the melt rate (for time cycle analyses assume not capacity limiting, assume about $9 x$ current waste processing capacity). The increased temperature provides much more flexibility in formulating glass while providing a highly durable product.

If the melter offgas generation rate and composition are such that the cell cannot accommodate the appropriately sized SBS, a quench tank and ejector venturi scrubber would be necessary to serve the same function as indicated in the Phase 1 study (Shah, 1993). For this study, it was assumed that the quench tank and ejector venturi scrubber are used. The condensate from the catch tank is recycled to the process waste treatment system as appropriate. The treated melter condensate waste solids are recycled to the vitrification process.

The balance of the vitrification flowsheet is the same as the reference design case.

Canisters, process waste/effluent, and samples will be generated at a substantially higher rate than in the design case. The design analysis in the Phase 1 study (Shah, 1993) applies, and the results are applicable. 


\subsection{HAJOR CHANGES TO THE CURRENT FLOHSHEET}

With notable exceptions, the simplified high capacity flowsheet uses the same process equipment as the current reference flowsheet which is described in Appendix A. The principle changes in the current reference flowsheet are as follows.

- The reductant is changed from formic acid to one that does not generate significant hydrogen or ammonia. There are no chemical reactions (see exception below) on reductant addition that limit the reductant addition rate or require a digestion period. The only potential reductant, if used in the acid form, chemical reactions on addition is neutralization which could lead to $\mathrm{CO} 2$ and $\mathrm{NxOy}$ generation if the slurry $\mathrm{pH}$ is allowed to decrease below about eight. Potential reductants are butyric acid, citric acid, and tartaric acid and their sodium forms together with sugar and starch. Sugar is used in the Hest Valley vitrification process.

- The glass forming frit (fresh process frit) is directly added as a dry component to the melter. Current German vitrification technology employs this step. In addition to simplifying the flowsheet, the potential problem of melter feed rheology change due to frit solubility may be avoided. There is some potential that the canister decontamination frit recycle still may affect melter feed properties.

- The melter used is a high temperature stirred melter. It is assumed that this melter has a waste processing capacity well above four times the current reference melter capacity based on considerations made in the Phase 1 study (Shah, 1993). High temperature and stirred melter technology are currently under development by the Department of Energy at Hanford and Savannah River Plant respectively. The high temperature stirred melter would implement the advantages of the high temperature melter of high waste loading, increased glass formulation flexibility, and increased processing rate together with the stirred melter which increases capacity throughput. The concept is a high temperature melter with a stirrer in the tank. This approach is a modest extension of the individual melter technologies which has not been currently tested and may provide some materiais performance chalienges. 
Implementing these changes may have a cascading effect such that one change may necessitate the need for other changes to make the process operate effectively. Thus, the impacts of the recommended changes need to be considered in greater detail to assure satisfactory overall process performance.

Other significant changes to feed preparation, that were considered in the Phase 1 study and further considered here and the Phase II study include the option to maximize the concentration of the HWV feed. The concentration of the HWVP feed received has such a major impact on the feed preparation time cycle that the concentration needs to be maximized within the constraints of cost/benefit of other options as considered in this study. Other alterations include parallel feed preparation operations and increasing batch sizes.

Other beneificial process changes that should be evaluated, but are not included in this study are the following:

- Routing the canister decontamination waste back to the tank farm to be combined with the HWV feed for concentration and recycle. This action would further simplify the process and eliminate an internal plant recycte stream which adds process operations complexity. Also the evaporation load on the plant would be decreased. If the decontamination solution is non-transuranic and $10 w$ in radionuclides, the condensate can be sent directly to the tank farm as low level waste. A line, if not available, would have to be provided from the plant to the tank farm to enable recycle to the HWVP feed for concentration.

- The Submerged Bed Scrubber (SBS) may be operated at an elevated temperature to retain the water as a gas through the High Efficiency Mist Eliminator (HEME). Then the gas temperature is decreased for water condensation. The non-transuranic and very low radionuclide content condensed solution can then be routed directly to the tank farm after neutralization for treatment as low level waste. This process modification, in effect, adds additional evaporation capacity to the pialli alú reúces the feed preparation or tine waste treatment iime cycle. To implement this modification a condenser-condensate collector would have to be installed. 
- The melter may be made with a sloped bottom and inciude a routine-use bottom drain. The sloped bottom and bottom drain would allow solids settling in the melter to be periodically flushed from the melter into the canister. This would extend the life of the melter if limited by solids accumulation. A review would have to be performed to ascertain if a melter with an adequately sloped bottom and bottom drain would fit into the existing HWVP cell and the changes needed to accommodate these melter modifications. Overflow pouring would be retained. These options are being included in part in current studies.

- The flexibility to accommodate a larger canister need be considered. This would lead to the production of fewer canisters that would have to be handled in the HWVP, shipped, and handled by the repository.

- The filled canister decontamination process should be reassessed. Using the Ce+4 decontamination process being employed at the West Valley Demonstration Project should be considered in addition to other approaches. Frit blasting for canister decontamination may have several drawbacks in slurry handling including ability to obtain representative samples, plugging pipes and fittings such as Purex nozzles, and maintaining the frit in suspension in addition to cost, complexity and reliability. Current irdications are that the Cei4 process time cycle for a single unit may not be compatible with high capacity HWVP and multiple units would be needed.

\subsection{PROCESS TIME CYCLE ANALYSES}

The process time cycle analyses are performed in this section to determine the capacity of the simplified high capacity flowsheet. The feed preparation time cycles developed are those for the SRAT and SME which are capacity limiting with an advanced melter such as the stirred, high temperature melter that has a capacity up to nine times the current design capacity. The SRAT and SME time cycles for the reference flowsheet are in Appendix A. The SRAT and SME time cycles for the simplified high capacity flowsheets are included in Tables 1 and 2 . There should be no limitations for the MFT operating at a capacity compatible with the melter capacity study range. This melter capacity assumption is similar to that used in the phase 1 
study (Shah, 1993). The time cycle analyses do not include process idle times which for final process analyses need to be included.

The basis for the time cycle analyses is one melter feed batch. The assumptions used in generating the time cycles in Tables 1 and 2 are provided below:

- The MFT batch size: 6090-gal (current design)

- Feed concentration to HWVP: $25 \mathrm{~g} / \mathrm{L}$ of waste oxides (WO) (current design)

- Concentrated waste slurry concentration: $125 \mathrm{~g} / \mathrm{L}$ of h'D (current design)

- The waste loading in the glass is $25 \mathrm{wt} \%$ on an oxide bases (current. design).

- One canister contains $3630 \mathrm{lb}(1650 \mathrm{~kg})$ glass (current design).

- One melter feed batch produces 7 canisters

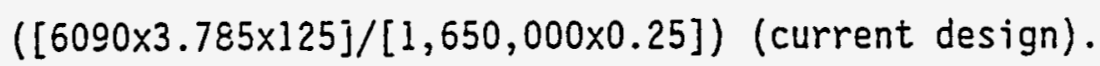

The time cycle analyses impacts on HWVP capacity are shown in Table 3. For the reference case with the DWPF melter the plant capacity with the melter limiting capacity is $100 \mathrm{~kg} / \mathrm{h}$ of glass. If an advanced melter is installed that has a capacity up to nine times the DWPF melter then, without idle time, the hiliV capacity is $150 \mathrm{~kg} / \mathrm{h}$ of glass. The SRAT processing requirements becomes limiting. If the simplified high capacity flowsheet is used in conjunction with the advanced melter without idle times the HWVP capacity becomes $215 \mathrm{~kg} / \mathrm{h}$ of glass.

To substantially further increase HIVP capacity, additional heat transfer capacity for evaporation and cooling whether in or out of the plant is required for boiling and cooling. Additional analyses to further increase the Hilp capacity are discussed in the next section. 
TABLE 1. SIMPLIFIED HIGH CAPACITY FLOHSHEET REFERENCE MODIFICATION - SRAT TIME CYCLE

\begin{tabular}{|c|c|c|c|}
\hline $\begin{array}{l}\text { Process } \\
\text { Step } \\
\text { Number }\end{array}$ & Process Step Description & $\begin{array}{l}\text { Process } \\
\text { Step } \\
\text { Time, h }\end{array}$ & $\begin{array}{l}\text { Cunulative } \\
\text { Process } \\
\text { Time, } \mathrm{h} \\
\end{array}$ \\
\hline 0 & SRAT batch heel ( 0 gal batch volume) & 0.0 & 0.0 \\
\hline 1 & $\begin{array}{l}\text { Receive HWWP feed at } 100 \mathrm{gpm}(25 \mathrm{~g} \text { W0/1, } 6090 \mathrm{gal} \text { incl } 120 \mathrm{gat} \\
\text { flush) }\end{array}$ & 1.25 & 1.25 \\
\hline 2 & lleat tank contents to boiling $\left(7780 \mathrm{gal}, 123^{\circ} \mathrm{F} \rightarrow 214^{\circ} \mathrm{F}\right)$ & 1.8 & 3.05 \\
\hline 3 & $\begin{array}{l}\text { Concentrate tank contents at evaporation rate of } 10 \text { gpm while } \\
\text { receiving additional feed volume }(23,460 \text { gal; final batch } \\
\text { volume, excluding heel, } 6030 \text { gal) }\end{array}$ & 40.0 & 43.05 \\
\hline 4 & Cool tank contents for transfer $\left(7720 \mathrm{gal}, 214^{\circ} \mathrm{F} \rightarrow 123^{\circ} \mathrm{F}\right)$ & 9.7 & 52.75 \\
\hline 5 & $\begin{array}{l}\text { Transfer concentrated feed to SME at } 100 \mathrm{gpm}(121 \mathrm{~g} \mathrm{W0} / 1,6090 \\
\text { !al; incl } 60 \mathrm{gal} \text { flush/prime water) }\end{array}$ & 1.25 & 54.00 \\
\hline & & & \\
\hline & & & \\
\hline & $=$ & & \\
\hline
\end{tabular}


TABLE 2. SIMPLIFIED HIGH CAPACITY FLOHSHEET REFERENCE MODIFICATION -

\section{SME TIME CYCLE}

\begin{tabular}{|c|c|c|c|}
\hline $\begin{array}{l}\text { Process } \\
\text { Step } \\
\text { Number }\end{array}$ & Process Step Description & $\begin{array}{l}\text { Process } \\
\text { Step } \\
\text { Time, } h\end{array}$ & $\begin{array}{l}\text { Cumulative } \\
\text { Process }\end{array}$ \\
\hline 0 & SME batch heel ( 0 gal batch volume) & 0.0 & 0.0 \\
\hline 1 & $\begin{array}{l}\text { Receive concentrated feed from SRAT at } 100 \mathrm{gpm}(121 \mathrm{~g} \mathrm{W0} / 1 \text {, } \\
6090 \mathrm{gal} \text { incl } 60 \mathrm{gal} \text { flush/prime water) }\end{array}$ & 1.25 & 1.25 \\
\hline 2 & Heat tank contents to boiling $\left(7780 \mathrm{gal}, 123^{\circ} \mathrm{F} \rightarrow 214^{\circ} \mathrm{F}\right)$ & 1.1 & 2.35 \\
\hline 3 & $\begin{array}{l}\text { Concentrate tank contents at evaporation rate of } 10 \mathrm{gpm} \text { to } \\
\text { allow chemical addition for melter feed makeup. During } \\
\text { concentration add the following for melter feed makeup: }(4192 \\
\text { gal evap). }\end{array}$ & 7.0 & $9.3 j$ \\
\hline $3 a$ & $\begin{array}{l}\text { As room available, receive RWCT process waste recycle at } 100 \\
\text { gpm. Assume canister decontamination waste including DWTT } \\
\text { concentrate transferred to RWCT in two batches. Assume: } \\
\text { i. Receive spent frit slurry at } 100 \mathrm{gpm} \text {, includes DWTT } \\
\text { concentrate ( } \mathrm{g} \text { WO/ } 2025 \mathrm{gal} \text { incl. prime/flush } \\
\text { water) and reheat to } 214^{\circ} \mathrm{F} \\
\text { ii. Repeat } i\end{array}$ & $\begin{array}{l}(0.5) \\
(0.5)\end{array}$ & $\cdot$ \\
\hline $3 b($ or 7$)$ & $\begin{array}{l}\text { Receive reductant from cold chemical makeup at } 10 \mathrm{gpm}(0-\mathrm{g} \\
\text { W0/1). Assume the reductant volume is the same as formic } \\
\text { acid, } 142 \text { gal }\end{array}$ & $(0.25)$ & \\
\hline 4 & $\begin{array}{l}\text { Cool tank contents for sampling, chemical adjustment, and } \\
\text { transfer to the MFT }\left(7780 \text { gal, } 214^{\circ} \mathrm{F} \rightarrow 123^{\circ} \mathrm{F}\right)\end{array}$ & 11.1 & 20.45 \\
\hline 5 & Sample tank contents & 0.5 & 20.95 \\
\hline 6 & Analytical hold time & 8.0 & 28.95 \\
\hline
\end{tabular}




\begin{tabular}{||l|l|c|c|}
\hline $\begin{array}{c}\text { Process } \\
\text { Step } \\
\text { Number }\end{array}$ & \multicolumn{1}{|c|}{ Process Step Description } & $\begin{array}{c}\text { Process } \\
\text { Step } \\
\text { Time, }\end{array}$ & $\begin{array}{c}\text { Cumulative } \\
\text { Process }\end{array}$ \\
\hline 8 & Chemical adjustment (as required) & 2.0 & 30.95 \\
\hline 9 & $\begin{array}{l}\text { Transfer melter feed to MFT at a rate of } 100 \mathrm{gpm}(200 \mathrm{~g} \mathrm{w0/7}, \\
\text { 6110 gal, incl prime/f7ush water) }\end{array}$ & 1.25 \\
\hline & & 32.2 \\
\hline
\end{tabular}


TABLE 3. HWYP WASTE PROCESSING CAPACITY

\begin{tabular}{|c|c|}
\hline Modifications & $\frac{\text { Available Melter Feed }}{\text { Rate, } \mathrm{kg} / \mathrm{h}}$ \\
\hline \multicolumn{2}{|l|}{ Current flowsheet (Shah, 1993): } \\
\hline Reference flowsheet & 100 \\
\hline No idle time (Includes Advanced Melter) & 150 \\
\hline Melter feed concentration: $600 \mathrm{~g} \mathrm{W0/1}$ & 120 \\
\hline Increase batch volume size: 7280 gal & 120 \\
\hline $\begin{array}{l}\text { Combination of no idle time, increase melter feed concentration }(600 \mathrm{~g} \\
.10 / 7) \text {, and increase batch volume size }\end{array}$ & 216 \\
\hline $\begin{array}{l}\text { (Increase feed concentration } 0.09 \mathrm{~kg} \text { w0/1 with no idle time, SME cycle } \\
\text { limit.): }(11,640 \mathrm{~kg} / 50.2 \mathrm{~h}, \text { SME cycle } 7 \text { imit) This case not in (Shah, } \\
\text { 1993). }\end{array}$ & 232 \\
\hline $\begin{array}{l}\text { Simplified high capacity flowsheet with no idle time: }(11,640 \mathrm{~kg} / 54 \mathrm{hr} \text {, SRAT } \\
\text { cycle limit) }\end{array}$ & 215 \\
\hline $\begin{array}{l}\text { Paral7el operated SRAT/SME with no idle time using simplified high capacity } \\
\text { flowsheet (el iminate } 9.7 \mathrm{~h} \text { SRAT cool and } 1.25 \mathrm{~h} \text { SRAT transfer) }: 2[11,640 \mathrm{~kg} /(54 \\
\mathrm{h}-10.95 \mathrm{~h}+32.2 \mathrm{~h}-1.25 \mathrm{~h})]\end{array}$ & 315 \\
\hline $\begin{array}{l}\text { Sinplified high capacity flowsheet using three sleam coils and cooling jacket on } \\
\text { SRAT and SME: (See Appendix ()) }\end{array}$ & 310 \\
\hline $\begin{array}{l}\text { Parallel operated SRAT/SME using three steam coils and cooling jacket on } \\
\text { SRAT/SME with no idle time using simplified high capacity flowsheet: } 2[11,640 \\
\mathrm{kg} /(37.5 \mathrm{~h}-10.95 \mathrm{~h}+24.7 \mathrm{~h}-1.25 \mathrm{~h})]\end{array}$ & 465 \\
\hline
\end{tabular}




\begin{tabular}{|c|c|}
\hline Modifications & $\frac{\text { Available Melter Feed }}{\text { Rate, } \mathrm{kg} / \mathrm{h}}$ \\
\hline $\begin{array}{l}\text { Simplifind high capacity flowsheet with no idle time and increased feed } \\
\text { cuncentration }(0.09 \mathrm{~kg} \text { WO/1): }(11,640 \mathrm{~kg} / 32.2 \mathrm{hr} \text {, SME cycle } 7 \mathrm{imit}) \text {, Sec Appendix } \\
\text { C for SRAT cycle. }\end{array}$ & 361 \\
\hline $\begin{array}{l}\text { Simpl ifind high capacity flowshect: with no idle time, increased feed } \\
\text { concentration }(0.09 \mathrm{~kg} \text { W0/1), and waste recycle concentration performed in SRAT: } \\
(11,640 \mathrm{~kg} /(54 \mathrm{~h}-40 \mathrm{~h}+3.6 \mathrm{~h}+7.0 \mathrm{~h} \text {, SRAT cycle } 1 \text { imit) }\end{array}$ & 473 \\
\hline $\begin{array}{l}\text { Purallel operated SRAT/SME using three steam coiis and cooling jacket on } \\
\text { SIRAT/SME with no idle time using simplified high capacity flowshect, and } \\
\text { illcreased feed concentration }(0.09 \mathrm{~kg} \text { W0/1): (2[11,640 kg/(37.5 h-1.25 } \mathrm{h}-5.1 \\
-28.6 \mathrm{~h}+3.63 \mathrm{~h}+24.7 \mathrm{~h}-1.25 \mathrm{~h}])\end{array}$ & 785 \\
\hline $\begin{array}{l}\text { Simplified high capacity flowsheet using three steam coils and cooling jacket on } \\
\text { SRAT/SME with no idle time and increased process s7urry concentration }(175 \mathrm{~g} / 1 \\
\text { of WO): [(1l,640 kg) }(175 \mathrm{~g} / 1 / 125 \mathrm{~g} / 1)] /(54 \mathrm{~h}+0 \mathrm{~h}-0.5 \mathrm{~h}-4.6 \mathrm{~h}) \text {, } \\
\text { Alpendix C for SRAT cycle. }\end{array}$ & 333 \\
\hline $\begin{array}{l}\text { Simplificd high capacity flowsheet with no idle time, increased feed } \\
\text { concentration }(90 \mathrm{~g} / \mathrm{h} \text { W0 }) \text { and increased process slurry concentration }(175 \mathrm{~g} / 1 \\
\text { of W0): }[(11,640 \mathrm{~kg} / \mathrm{h})(175 \mathrm{~g} / 1 / 125 \mathrm{~g} / 1)] /(32.2 \mathrm{~h}-5.3 \mathrm{~h}+0.3 \mathrm{~h} \text {, SME cycle } \\
\text { limit) }\end{array}$ & 610 \\
\hline
\end{tabular}




\subsection{ADDITIONAL OPTIONS ANALYSES}

The essential factor in addition to flowsheet simplification (i.e. reducing the number of process steps) to obtain a major capacity increase is water management. The HWVP capacity can be increased by a factor of about two by flowsheet simplification and using an advanced melter. Increasing the capacity by a factor of up to five in waste processing capacity requires an effective increase in slurry evaporation and cooling capacity. There are also effective methods to increase melter feed batch size which will also modestly increase the HWVP capacity by up to 20 percent which are discussed in the Phase 1 study (Shah, 1993), see Table 3, and performing parallel feed preparation processes in the SRAT and SHE even further increases plant capacity.

Methods to effectively and substentially increase HWV heat transfer capacity which are included in this study are as follows. Convert the single cooling coils in the SRAT/SME/DWTT into coils that can be used for heating and place a cooling jacket on each tank. This option is analyzed in Appendix $C$. As shown in Table 3 by using three heating coils in the tanks and placing a 7 ft. high cooling jacket on each tank the plant capacity without idle time and the simplified high capacity flowsheet may be increased to $310 \mathrm{~kg} / \mathrm{h}$ of glass.

A major effective increase in SRAT evaporation rate can also be achieved by increasing the HWVP feed concentration from the tank farm (Shah, 1993). The waste concentration to the HWVP can be increased by installirig evaporation capacity in the HWVP tank farm lag storage or modified pretreatment steps. The Phase 1 study (Shah, 1993) indicated that the HWV feed concentration could be increased from $25 \mathrm{~g} / \mathrm{L}$ of wo to $90 \mathrm{~g} / \mathrm{L}$ which would decrease the SRAT evaporation time from $40 \mathrm{~h}$ to about $4 \mathrm{~h}$ at the nominal evaporation rate which would result in a SRAT. capacity increase to $360 \mathrm{~kg} / \mathrm{h}$ of glass without idle time and using the simplified high capacity flowsheet. If the flowsheet is further modified by performing the process waste recycle concentration in the SRAT the HWVP capacity can be further increased to $470 \mathrm{~kg} / \mathrm{hr}$ of $g$ lass. 
Another step in simplifying the flowsheet and increasing the capacity using the simplified high capacity flowsheet is to perform the SRAT and SME processes in one tank and in parallel. The SRAT and the SME would be used and operate in parallel. This approach eliminates the series step of cooling the SRAT contents and transferring the contents to the SME. Implementing this approach without any lag times and using the simplified high capacity flowsheet would result in a capacity increase to $315 \mathrm{~kg} / \mathrm{h}$ of glass.

Combinations of using an advanced melter, the simplified high capacity flowsheet, increasing effective HWVP evaporation capacity, and operating SRAT and SME as parallel feed preparation systems can be used in combination and with approaches in the Phase 1 study (Shah, 1993) including increasing batch volume size and increasing process stream concentration. These combinations could increase the HWVP capacity to well over $400 \mathrm{~kg} / \mathrm{h}$ of glass without idle times. The latter two options should be closely considered since their implementation reduces the analytical load per kilogram of glass produced.

Increasing the process waste concentration to between $150 \mathrm{~g} / 1$ of 110 to $200 \mathrm{~g} / 1$ of $\mathrm{HO}$ (use $175 \mathrm{~g} / 1$ of WO) increases the effective SRAT/SME/MFT batch size by about $40 \mathrm{v01. \% .} \mathrm{The} \mathrm{slurry} \mathrm{concentration} \mathrm{is} 1$ imited to about $175 \mathrm{~g} / 1$ of wo due to the significant increase in viscosity which will limit slurry transfer rates, agitation, and sampling. This option is most attractive when combined with an increase in heat transfer capacity. Using the simplified high capacity flowsheet and additional tank heat transfer area together with the increased process slurry concentration will result in the glass processing capacity being increased to $333 \mathrm{~kg} / \mathrm{h}$ of glass. If the HWVP feed concentration is increased to $90 \mathrm{~g} / 1$ of $\mathrm{k}^{\prime} \mathrm{O}$ with the simplified flowsheet and the increased. concentration is used, the SME time cycle becomes limiting and the glass processing capacity is increased to about $610 \mathrm{~kg} / \mathrm{h}$ of $\mathrm{glass}$.

Operating the SRAT and SME in parallel to perform the simplified high capacity flowsheet and increasing the heat transfer areas in each tank further increases the HWVP capacity to $465 \mathrm{~kg} / \mathrm{h}$ of glass excluding idle time. 
If the combination of options is employed to use the simplified high capacity flowsheet, parallel SRAT/SME feed preparation systems, increased HWVP feed concentration, and increased SRAT/SME/DWTT heat transfer areas without idle times then the HWVP capacity could be increased to $785 \mathrm{~kg} / \mathrm{h}$ of glass.

Increasing the SRAT/SME/MFT batch size from $6100 \mathrm{gal}$ to $7280 \mathrm{gal}$ will further increase processing capacity. The Phase 1 study (Shah, 1993) indicates that this modification could increase capacity to $120 \mathrm{~kg} / \mathrm{h}$ of glass. Increasing the slurry concentration to $175 \mathrm{~g} / 1$ of $\mathrm{kO}$ will al so modestly increase the HWVP capacity where used.

The glass process capacities indicated here are for comparative purposes. Actual values for plant production need to include delay times between steps and a more definitive engineering analyses. 


\subsection{FACILITY AND EQUIPMENT IMPACTS}

Impacts of implementing the simplified high capacity flowsheet on the facility and equipment are discussed in this section. The simplified flowsheet was defined such that it would have no major impacts on the Vitrification Building structure. Facility modifications required for other process modifications assessed in this study are aiso discussed. This study identifies major equipment modifications needed to obtain a feed processing capacity increase of four to five times the current design capacity.

Subsequent more detailed studies will be necessary to adequately define all plant implementation impacts.

Simplified high capacity flowsheet implementation will require the following major system modifications:

- The current melter would be replaced by an advanced melter, such as the stirred, high temperature liquid fed ceramic melter (SHLM), with the capability for controlled dry frit feeding. Routine bottom draining would be an asset for flexibility and keeping melter bottom clean. A high capacity melter is needed for any HWVP capacity increase scenario.

- Changing the reductant from formic acid to some other organic may require minor facility and equipment changes. Depending on the reductant selected, whether liquid or a solid requiring dissolution, there may be some chemical makeup and transport modifications needed. There is the possibility that eliminating the use of formic could lead to equipment simplification related to ammonia and hydrogen control along with hazards control for formic acid. Depending on which tank, SRAT or SME, or both that the reductant is added to, some minor piping modifications may be needed. Since the reductant would likely be added at a rate up to $20 \mathrm{gpm}$, the transport system would likely have to be increased in capacity.

- To increase the concentration of the process feed slurries (study: 175 $\mathrm{g} / \mathrm{l}$ of $\mathrm{WO}$ ) in conjunction with the simplified flowsheet no facility/equipment modifications are required. Some assessment is neaded to assure that the process slurry composition and concentration selected is compatible with equipment performance. 
To substantially further increase the HWVP capacity to attain a $4 X$ or $5 X$ capacity other modifications are needed as indicated in previous sections. These modifications are subsequently discussed.

- The modification which would be most beneficial to increasing HWVP capacity is increasing the concentration of the HWVP feed received to whatever is the maximum practical from the tank farm or pretreatment. The required changes would not impact the current HWVP design. This capability would likely affect other future Hanford waste management facilities. This option should be further investigated for implementation. This approach would greatly benefit the current HWVP design compatibility with high capacity flowsheets by alleviating water and waste management in the plant.

- SRAT/SME/OWTT heat transfer system modifications are needed to increase

the heating heat transfer capacity by $40 \%$ and double the cooling capacity. The cooling coil in each tank would have services modified to accommodate heating duty. The ability of the system to retain cooling capability if desired would be desirable flexibility. A cooling jacket would be installed on each tank. The condenser heat transfer capacity would have to be increased commensurate with the increase in heat transfer capacity. The services and instrumentation need to be assessed for compatibility with the capacity increases.

- To accommodate parallel operation of the SRAT and SME as independent and parallel feed preparation systems; services, routes, and instrumentation to enable all of the required steps are needed.

- There is also significant incentive to maximize the feed preparation batch sizes. There are many minor modifications which can be easily implemented to accomplish this goal and should be pursued. Many of modifications are treated in the Phase I study (Shah,1993) and are being further pursued by WHC/FIuor in the Phase 2 study. These modifications will not be treated here.

Implementation of primary changes discussed above will have secondary process affects which, depending on the changes made, will require additional facility modifications. The major areas of secondary impact are canister handling, waste/effluent handling, and analytical support. The majority of 
these impacts are a direct result of the capacity increase and are only modestly impacted by which of the above modifications are implemented. These secondary effects are treated in the Phase 1 study (Shah, 1993) and are being addressed in the Phase 2 study in progress. Primary changes that would significantiy mitigate secondary impacts are increasing HWWP feed concentration to the plant, increasing process feed slurry concentration, increasing batch size, and increasing canister size. 


\subsection{DEVELOPHENT REQUIREMENTS}

The system modifications selected for this study are extensions or modifications of existing technologies that would take up to five years or less to verify for HWVP implementation. No significant increases in the currently planned development budgets are envisioned for developing the modifications. The following discussion indicates system development requirements with basic required development times and preliminary budgets for HWVP implementation. The full budget and time indicated are not needed to determine if the system modifications are feasible for HWVP implementation.

The following development is needed:

- New reductant: A new reductant such as citric acid, tartaric acid, or butyric acid is needed. Studies are necessary to determine amount needed per batch and chemistry/rheology characteristics including any reactions such as gas generation that may affect processability and affect the waste processing rate in the melter, and affects on slurry properties for pumping and agitation.

- Projected Budget: $\$ 2 M$

- Schedule: 2 yrs

- Melter feed makeup and properties: The new melter faed makeup/preparation procedure should be tested. The associated high concentration slurry processing properties need to be assessed for pumping, agitation, melter feeding, heat transfer, and process performance in the laboratory and on an engineering scale. A largescale integrated demonstration would be performed. The large scale demonstration would include increased tank heat transfer if implemented.

- Projected Budget: $\$ 3 M$

- Schedule: 3 yrs

- Stirred, High Temperature Liquid Feed Melter With Controlled Direct Dry Frit Feeding (And Routine Bottom Draining): The current High Temperature and Stirred Melter programs would be consolidated to demonstrate the melter concept. Some development has already been periormed and is discussed in the Phase 1 repori (Shan, 1993). The direct frit feed and bottom drain systems may be an adaptation of the 
systems, being used by the Germans. Also, melter empty-out systems are in current U.S. melter designs. Verification of the routine operation of a bottom drain valve and over flow such as used by the Germans would be demonstrated. Bottom draining would facilitate the removal of any solids buildup in the melter. A stirred, high temperature melter further challenges melter materials performance due to temperature and flow conditions. Other areas of development testing would include system component testing and integrated system testing, materials testing, electrode operations/life, component volatility, processing capacity, waste loading, glass quality, process control, equipment. operations/reliability, and glass formulation.

- Projected Budget: $\$ 15 \mathrm{M}$

- Schedule: 5 yrs

These costs include budget to demonstrate the modifications described and replace related equivalent development areas. Not included in these costs are items already in the existing development budgets. As a result of further evaluation and engineering analyses other development items may be identified. 


\subsection{ALTERNATIVE EVALUATION}

Evaluating the simplified high capacity flowsheet and other process/equipment modifications consists of qualitatively indicating advantages, disadvantages, cost impacts, and schedule impacts in regard to study bases and objectives. Each major modification is individually considered in Table 4. Combinations of modifications oriented toward meeting study objectives are not included in Table 4. However, selected combinations of modifications which are anticipated to be attractive were previously indicated in Table 3. No one modification considered here will achieve a $4 X$ or $5 X$ capacity increase. Each modification provides a significant capacity increase, but when combined with other modifications results in major capacity increases up to $5 X$ or more. None of the modifications proposed has a direct major impact on the Vitrification Building "footprint."

The high capacity melter is needed in any capacity increase scenario since the melter is currently capacity limiting. A melter capacity increase of up to $9 \mathrm{X}$ would be appropriate so that the melter does not again become capacity limiting. The melter should be flexible to handle the a wide variety of feed compositions at high capacity while producing a high quality glass at high waste loadings (high temperature and stirred). Normal bottom draining in conjunction with a sloped bottom is an operating life extension feature. Direct process frit feeding is an approach to significantly simplify SME processing, reduce the ShE time cycle, and reduce waste water generation.

Once the melter capacity limit is removed, SRAT processing becomes capacity limiting. The SRAT time cycle limit can be removed by significantly increasing the HWVP feed concentration which has no HWVP impacts. In lieu of the concentration increase, a variety of modification combinations can be used to make the SRAT time cycle non-limiting. Then additional decreases in the SRAT and SME time cycles further increase HWVP capacity. Without further study to determine the cost and related benefit returns including any secondary effects, there is significant uncertainty in ranking modifications. A significant case could be made to pursue all of the modifications indicated. 
Within study guidelines and modifications evaluation (Table 4), the author judges that implementation of the modifications should pursued in the following order:

- Install high capacity melter,

- Maximize HWVP feed concentration to plant,

- Use alternative reductant,

- Implement direct dry process frit feeding to the melter,

- Maximize process feed slurry concentrations,

- Increase batch sizes,

- Increase SRAT/SME/DWTT heat transfer areàs, and

- Perform paraliel feed preparation processes. 
TABLE 4. COMPARISON OF CAPACITY INCREASE MODIFICATIONS

\begin{tabular}{|c|c|c|c|c|}
\hline Hodification & 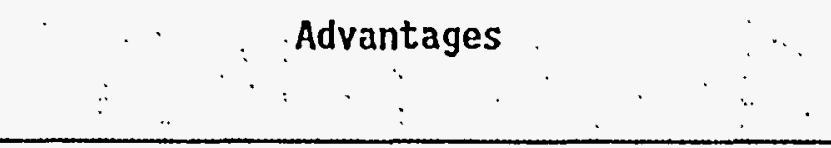 & $\begin{array}{l}\because \text { Disadvantages } \\
\vdots \\
\therefore\end{array}$ & $\begin{array}{l}\text { HWVP } \\
\text { Schedule } \\
\text { Impact }\end{array}$ & $\begin{array}{l}\text { HivP } \\
\text { Cost } \\
\text { Impact }\end{array}$ \\
\hline $\begin{array}{l}\text { 1. Change } \\
\text { reductant to: } \\
\text { butyric acid, } \\
\text { tartaric acid, } \\
\text { citric acid, or } \\
\text { sugar }\end{array}$ & $\begin{array}{l}\text { Eliminate following SRAT steps. } \\
\text { - Cool to } 190 \circ \mathrm{F}(2 \mathrm{~h}) \\
\text { - Add formic acid ( } 6 \mathrm{~h}) \\
\text { - Reheat to boiling and } \\
\text { reflux ( } 4 \mathrm{~h}) \\
\text { - Sample }(0.5 \mathrm{~h}) \\
\text { - Analyses hold ( } 8 \mathrm{~h}) \\
\text { - Chemical adjustment } \\
\text { (as required [2h]) } \\
\text { (Reductant add and sampling moved } \\
\text { to SME, } \Delta=22.5 \mathrm{~h}) \\
\text { - Eliminate hydrogen generation and } \\
\text { associated HWV safety mitigation } \\
\text { requirements (SRAT/SME } \\
\text { condenser/vent system } \\
\text { modifications) } \\
\text { Eliminate ammonia generation. and } \\
\text { associated HWV safety mitigation } \\
\text { requirements (new vessel vent } \\
\text { scrubber) } \\
\text { Eliminate safety hazards and HWVP } \\
\text { requirements associated with } \\
\text { handling formic acid }\end{array}$ & $\begin{array}{l}\text { Requires } \\
\text { modification } \\
\text { of reductant } \\
\text { makeup/addi- } \\
\text { tion system. } \\
\text { Handling } \\
\text { capacity would } \\
\text { be increased } \\
\text { from } 2 \text { gpm up } \\
\text { to } 20 \mathrm{gpm} \text {. }\end{array}$ & $<1 \mathrm{yr}$ & $\begin{array}{l}\text { Minor } \\
\text { (potential } \\
\text { capital } \\
\text { cost } \\
\text { savings) }\end{array}$ \\
\hline
\end{tabular}




\begin{tabular}{|c|c|c|c|c|}
\hline Modification & 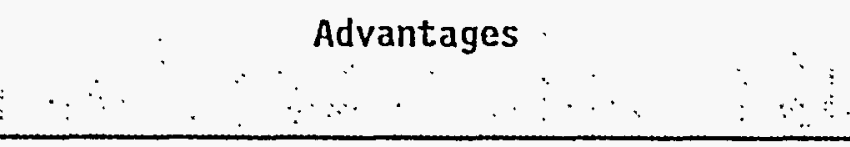 & $\begin{array}{l}\text { Disadvantages } \\
\vdots \\
\because \quad \vdots \quad \therefore \quad \\
\end{array}$ & $\begin{array}{c}\text { HWVP } \\
\text { Schedule: } \\
\text { Impact }\end{array}$ & $\begin{array}{l}\text { HIWVP } \\
\text { Cost } \\
\text { Impact }\end{array}$ \\
\hline $\begin{array}{l}\text { 2. Advanced } \\
\text { melter: high } \\
\text { temperature } \\
\text { stirred melter } \\
\text { with controlled } \\
\text { direct frit } \\
\text { addition. } \\
\text { Note: High } \\
\text { capacity melter } \\
\text { (high lenpera- } \\
\text { ture melter or } \\
\text { stirred melter) } \\
\text { required to make } \\
\text { capacity increase } \\
\text { viable. }\end{array}$ & $\begin{array}{l}\text { - Eliminate following SME steps with } \\
\text { direct frit add: } \\
\text { - Cool to } 125^{\circ} \mathrm{F}(8.4 \mathrm{~h}) \\
\text { - Sample }(0.5 \mathrm{~h}) \\
\text { - Heat to boiling (1.1h) } \\
\text { - Concentrate at } 10 \mathrm{gpm} \text { boilup (3h) } \\
\text { - Add fresh frit (1h) } \\
\text { - Add trim chemicals, reheat to } \\
\text { boiling, and reflux (as required) } \\
\text { ( } 2 \mathrm{~h}) \\
\text { Concentrate recycle steps } \\
\text { compressed by adding waste and } \\
\text { reductant during boiling (2h) (A } \\
\text { cycle }=18 h \text { with above) } \\
\text { A stirred high temperature melter } \\
\text { would use the high capacity } \\
\text { advantages of the stirred melter } \\
\text { with the high capacity, high waste } \\
\text { loading, and glass formulation } \\
\text { flexibility of a high temperature } \\
\text { melter. } \\
\text { Dry frit feeding reduces waste } \\
\text { generation }\end{array}$ & $\begin{array}{l}\text { Development } \\
\text { and design } \\
\text { progran may be } \\
\text { required to } \\
\text { provide } \\
\text { controlled } \\
\text { direct frit } \\
\text { (dry) feed } \\
\text { system to } \\
\text { melter (more } \\
\text { detail- } \\
\text { cngineering } \\
\text { study needed } \\
\text { to assess } \\
\text { technology } \\
\text { availability } \\
\text { from Germans } \\
\text { and } \\
\text { applicability } \\
\text { to HwVP) } \\
\text { nssociated } \\
\text { study may be } \\
\text { required to } \\
\text { assure product } \\
\text { quality is not } \\
\text { affected }\end{array}$ & $<3$ yrs & $\begin{array}{l}\text { Modest for } \\
\text { direct frit } \\
\text { feed } \\
\text { increment }\end{array}$ \\
\hline
\end{tabular}




\begin{tabular}{|c|c|c|c|c|}
\hline Modification & $\begin{array}{cc} & \text { Advantages } \\
\because & \\
\end{array}$ & Disadvantages. & $\begin{array}{l}\text { HWVP } \\
\text { ScheduTe } \\
\text { Impact }\end{array}$ & $\begin{array}{l}\text { HWVP } \\
\text { Cost. } \\
\text { Impact }\end{array}$ \\
\hline $\begin{array}{l}\text { 3. Increase } \\
\text { SRAT/SME/DWTT } \\
\text { heat ing }(40 \%) \text { and } \\
\text { coot ing }(90 \%) \\
\text { heat transfer } \\
\text { area }\end{array}$ & $\begin{array}{l}\text { - Reduce time for heating and cooling } \\
\text { steps in SRAT/SME } \\
\text { SRAT: } \Delta \text { time, } h \\
\text { Step: } \\
2 \text { heating } \quad 0.5 \mathrm{~h} \\
3 \text { boiling } \quad 11.4 h \\
4 \text { cooling } \frac{4.6 h}{16.5 h} \\
\text { SME: } \Delta \text { time, } h \\
2 \text { heating } \\
3 \text { boiling } 0.3 h \\
4 \text { cooling } \frac{0.2 h}{7.2 h} \\
\text { - Provides additional heat transfer } \\
\text { area in DWTT to meet increased load } \\
\text { from capacity increase. Need } \\
\text { assessment to see if adequate to } \\
\text { meet increased waste handling } \\
\text { requirements. }\end{array}$ & $\begin{array}{l}\text { Requires minor } \\
\text { IIWV design } \\
\text { changes: } \\
\text { - convert } \\
\text { SRAT/SME/ } \\
\text { DWTT cooling } \\
\text { coil to } \\
\text { heating } \\
\text { service. } \\
\text { - Add cooling } \\
\text { jackets to } \\
\text { SRAT/SME/ } \\
\text { DWTT } \\
\text { Assess heating } \\
\text { (and may be } \\
\text { cooling) } \\
\text { characteris- } \\
\text { tics of tank } \\
\text { to see if } \\
\text { increase in } \\
\text { heat transfer } \\
\text { area performs } \\
\text { as projected. }\end{array}$ & Minor & Modest \\
\hline $\begin{array}{l}\text { 4. Maximize con- } \\
\text { centrated feed } \\
\text { concentrations in } \\
\text { HWVP }(125 \mathrm{~g} / 1 \text { of } \\
\text { WO to } 175 \mathrm{~g} / 1 \text { of } \\
\text { WO used for } \\
\text { study) }\end{array}$ & $\begin{array}{l}\text { - Has effect of increasing batch size } \\
\text { by } 40 \% \text { and decreasing the time } \\
\text { needed for processing per gallon in } \\
\text { SRAT and SME except for initial } \\
\text { SRAT receiving and feed } \\
\text { concentration and steps that are a } \\
\text { function of the waste in the tanks. } \\
\text { Minimizes analytical requirements } \\
\text { per gallon of feed } \\
\text { No impacts on HWVP facility and } \\
\text { equipment }\end{array}$ & $\begin{array}{l}\text { Minor amount } \\
\text { of development } \\
\text { testing would } \\
\text { have to be - } \\
\text { performed to } \\
\text { determine what } \\
\text { is the maximum } \\
\text { concentration } \\
\text { the process } \\
\text { equipment can } \\
\text { handle }\end{array}$ & None & None \\
\hline
\end{tabular}




\begin{tabular}{|c|c|c|c|c|}
\hline Modification & $\begin{array}{l}\quad \text { Advantages } \\
\therefore \quad \\
\therefore\end{array}$ & Disadvantages & $\begin{array}{l}\text { HWVP. } \\
\text { Schedule } \\
\text { Impact }\end{array}$ & $\begin{array}{r}\text { HWVP } \\
\text { Cost } \\
\text { Impact }\end{array}$ \\
\hline $\begin{array}{l}\text { 5. Maximize con- } \\
\text { centration of } \\
\text { HWVP feed } \\
\text { transferred to } \\
\text { HWVP (study: } \\
25 \mathrm{~g} / 1 \text { of } \mathrm{WO} \rightarrow 90 \\
\mathrm{~g} / 1 \text { of } \mathrm{WO} \text { ) }\end{array}$ & $\begin{array}{l}\text { - Reduces time for SRAT feed } \\
\text { concentration step by about } 36.4 \mathrm{~h} \\
\text { which is time cycle limiting. } \\
\text { Enables performance of SHE process } \\
\text { waste concentration steps to be } \\
\text { performed in SRAT so not as to be } \\
\text { time cycle limiting: } \\
\text { SME: A time, h } \\
\text { Step } 2 \text { heating }-1.1 \mathrm{~h} \\
\text { Step } 3 \text { boiling }-7.7 \mathrm{~h} \\
\text { Step } 4 \text { cooling }-11 . \mathrm{h} \\
\text { This modification requires no } \\
\text { facility modifications in HWVP. If } \\
\text { want to perform SME steps in SRAT } \\
\text { some routing modifications will be } \\
\text { required. } \\
\text { Significantly decreases waste } \\
\text { condensate handling from SRAT. } \\
\end{array}$ & $\begin{array}{l}\text { Need to assess } \\
\text { impacts on } \\
\text { tank farm } \\
\text { and/or pre- } \\
\text { treatment } \\
\text { programs. }\end{array}$ & $\begin{array}{l}\text { None } \\
\text { directly }\end{array}$ & $\begin{array}{l}\text { None } \\
\text { directly }\end{array}$ \\
\hline $\begin{array}{l}\text { 6. Perform SRAT } \\
\text { and SME feed } \\
\text { preparation } \\
\text { process in SRAT } \\
\text { and SME, paraTle1 } \\
\text { feed preparation } \\
\text { operations. }\end{array}$ & $\begin{array}{l}\text { Eliminates process operations in } \\
\text { SRAT and SME. } \\
\text { SRAT: } \Delta \text { time, } h \\
\text { Step } \\
4 \text { cooling } \quad-9.7 \mathrm{~h} \\
5 \text { transfer } \frac{-1.25 \mathrm{~h}}{-10.95 \mathrm{~h}} \\
\text { SME: } \\
\text { Step } \\
1 \text { receive } \\
\text { SRAT slurry } \frac{-1.25 \mathrm{~h}}{-1.25 \mathrm{~h}}\end{array}$ & $\begin{array}{l}\text { Requires HWVP } \\
\text { design changes } \\
\text { to assure } \\
\text { routings are } \\
\text { provided to } \\
\text { enable } \\
\text { completely } \\
\text { parallel feed } \\
\text { preparations } \\
\text { in SRAT and - } \\
\text { SME }\end{array}$ & $<1 \mathrm{yr}$ & Modest \\
\hline
\end{tabular}




\begin{tabular}{|c|c|c|c|c|}
\hline Modification & $\begin{array}{ccc}\therefore & \text { Advantages } \\
\vdots & \vdots\end{array}$ & $\begin{array}{l}\because \text { Disadvantages } \\
\therefore \quad \cdots \\
\end{array}$ & $\begin{array}{l}\text { HHVP } \\
\text { Schedule } \\
\text { Impact }\end{array}$ & $\begin{array}{r}\text { Hrvp } \\
\text { Cost } \\
\text { Impact }\end{array}$ \\
\hline $\begin{array}{l}\text { 7. Maximize } \\
\text { process batch } \\
\text { size in SRAT and } \\
\text { SME (study uses } \\
6100 \text { gal } \rightarrow 7200 \\
\text { gal, 18\% } \\
\text { increase) }\end{array}$ & $\begin{array}{l}\text { Decreases the time needed for } \\
\text { processing per gallon in SRAT and } \\
\text { SME except for initial SRAT } \\
\text { receiving and feed concentration } \\
\text { and steps that are a function of } \\
\text { the waste in the tanks. Phase I } \\
\text { study (Shah, 1993) indicates that } \\
\text { there would be a } 20 \% \text { increase in } \\
\text { plant capacity). There would be an } \\
\text { improvement that would likely be } \\
\text { somewhat < } 10 \% \text { increase. } \\
\text { Minimizes analytical requirenents } \\
\text { per gallon of feed. }\end{array}$ & $\begin{array}{l}\text { SRAT and SME } \\
\text { design and } \\
\text { equipment } \\
\text { modifications } \\
\text { would have to } \\
\text { be made such } \\
\text { as modifying } \\
\text { the pump } \\
\text { intake and } \\
\text { intake } \\
\text { locations to } \\
\text { enable the } \\
\text { larger batch } \\
\text { volume. }\end{array}$ & Minor & Minor \\
\hline & & & & \\
\hline & & & & \\
\hline
\end{tabular}




\subsection{REFERENCES}

Shah, K. R., August 1993, "Hanford Waste Vitrification Plant Increased Production Capacity Evaluation (Phase I)," WHC-SD-HWV-ES-046, Westinghouse Hanford Company, Richland, WA 99352 
APPENDIX A

CURRENT FLOHSHEET DESCRIPTION AND TIME CYCLES 


\section{SLURRY RECEIPT AND ADJUSTMENT TANK TIME CYCLE}

Current Flowsheet

\begin{tabular}{|c|c|c|c|c|}
\hline $\begin{array}{l}\text { Process } \\
\text { Step }\end{array}$ & Process Step Description & $\begin{array}{c}\text { Step } \\
\text { Duration } \\
\text { (h) }\end{array}$ & $\begin{array}{c}\text { Time at } \\
\text { Start } \\
(h)\end{array}$ & $\begin{array}{c}\text { Time at } \\
\text { end } \\
\text { (h) }\end{array}$ \\
\hline 0 & SRAT heel & 0.0 & 0.0 & 0.0 \\
\hline 1 & Receive feed slurry at $100 \mathrm{gal} / \mathrm{min}$ & 11.25 & 0.0 & 1.25 \\
\hline 2 & Heat to boiling & 1.8 & 1.25 & 3.05 \\
\hline 4 & Cool to $190^{\circ} \mathrm{F}$ & 2 & 43.05 & 45.05 \\
\hline 5 & Add formic acid & 6 & 45.05 & 51.05 \\
\hline 6 & Reheat to boiling and reflux & 4 & 51.05 & 55.05 \\
\hline 10 & Chemical adjustment (as required) & 2 & 73.25 & 75.25 \\
\hline 11 & Transfer to SME at $100 \mathrm{gal} / \mathrm{min}$ & 1.25 & 75.25 & 76.5 \\
\hline 12 & SRAT idle & 39 & 76.5 & 115.5 \\
\hline 0 & SRAT hee1 & 0 & 115.5 & 115.5 \\
\hline
\end{tabular}




\section{SLURRY MIX EYAPORATOR TIME CYCLE Current Flowsheet}

\begin{tabular}{|c|c|c|c|c|}
\hline $\begin{array}{l}\text { Process } \\
\text { Step }\end{array}$ & Process Step Description & $\begin{array}{c}\text { Step } \\
\text { Duration } \\
\text { (h) }\end{array}$ & $\begin{array}{c}\text { Time at } \\
\text { Start } \\
\text { (h) }\end{array}$ & $\begin{array}{c}\text { Time at } \\
\text { end } \\
\text { (h) }\end{array}$ \\
\hline 13 & SME hee 1 & 0 & 0 & $\underline{0}$ \\
\hline 14 & Receive SRAT transfer & 1.25 & 0 & 1.25 \\
\hline $1 !$ & Heat to boiling & 1.1 & 1.25 & 2.35 \\
\hline 14 & Concentrate at $10 \mathrm{gal} / \mathrm{min}$ boilup & 3.5 & 7.85 & 11.35 \\
\hline 19 & Cool to $125^{\circ} \mathrm{F}$ & 3.4 & 11.35 & 19.75 \\
\hline $20^{\circ}$ & Sample & 0.5 & 19.75 & 20.25 \\
\hline 21 & Heat to boiling & 1.1 & 20.25 & 21.35 \\
\hline 24 & $\begin{array}{l}\text { Add trim chemicals, reheat to boiling, and } \\
\text { reflux (as required) }\end{array}$ & 2 & 25.35 & 27.35 \\
\hline $2 ! j$ & Cool to $125^{\circ} \mathrm{F}$ & 11.1 & 27.35 & 38.45 \\
\hline 26 & Sample & 0.5 & 38.45 & 38.95 \\
\hline 27 & Analytical hold & 8 & 38.95 & 46.95 \\
\hline 28 & Chemical adjustment (as required) & 2 & 46.95 & 48.95 \\
\hline 29 & Transfer to MFT at $100 \mathrm{gaT} / \mathrm{min}$ & 1.25 & 48.95 & 50.2 \\
\hline
\end{tabular}




\begin{tabular}{|l|l|c|c|c||}
\hline 30 & SME idle & 65.3 & 50.2 & 115.5 \\
\hline 13 & SME heel & 0 & 115.5 & 115.5 \\
\hline
\end{tabular}

NFT = Melter feed tank

RHCT $=$ Recycle waste collection tank

SME = Slurry mix evaporator

SRAT = Slurry receipt and adjustment tank 


\section{d encantine ticos}

(1) :

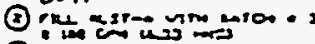

(2)

○ ?

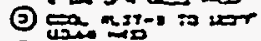

()

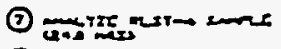

(1) 2.

(1) ع

(1)

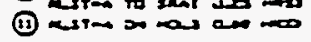

(3)

ق

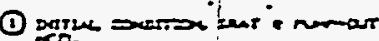

(1)

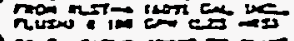

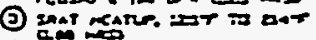

O

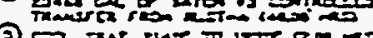

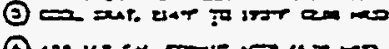

O O

(2) Dour ant ise

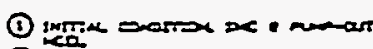

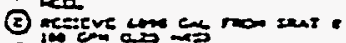

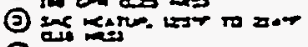

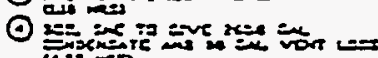

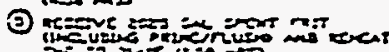

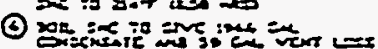

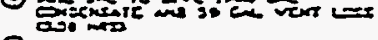

()

(O)

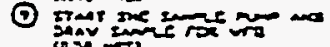

(3) 近

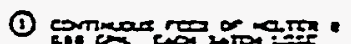
列 - Avten

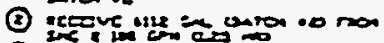

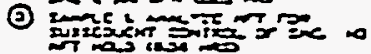
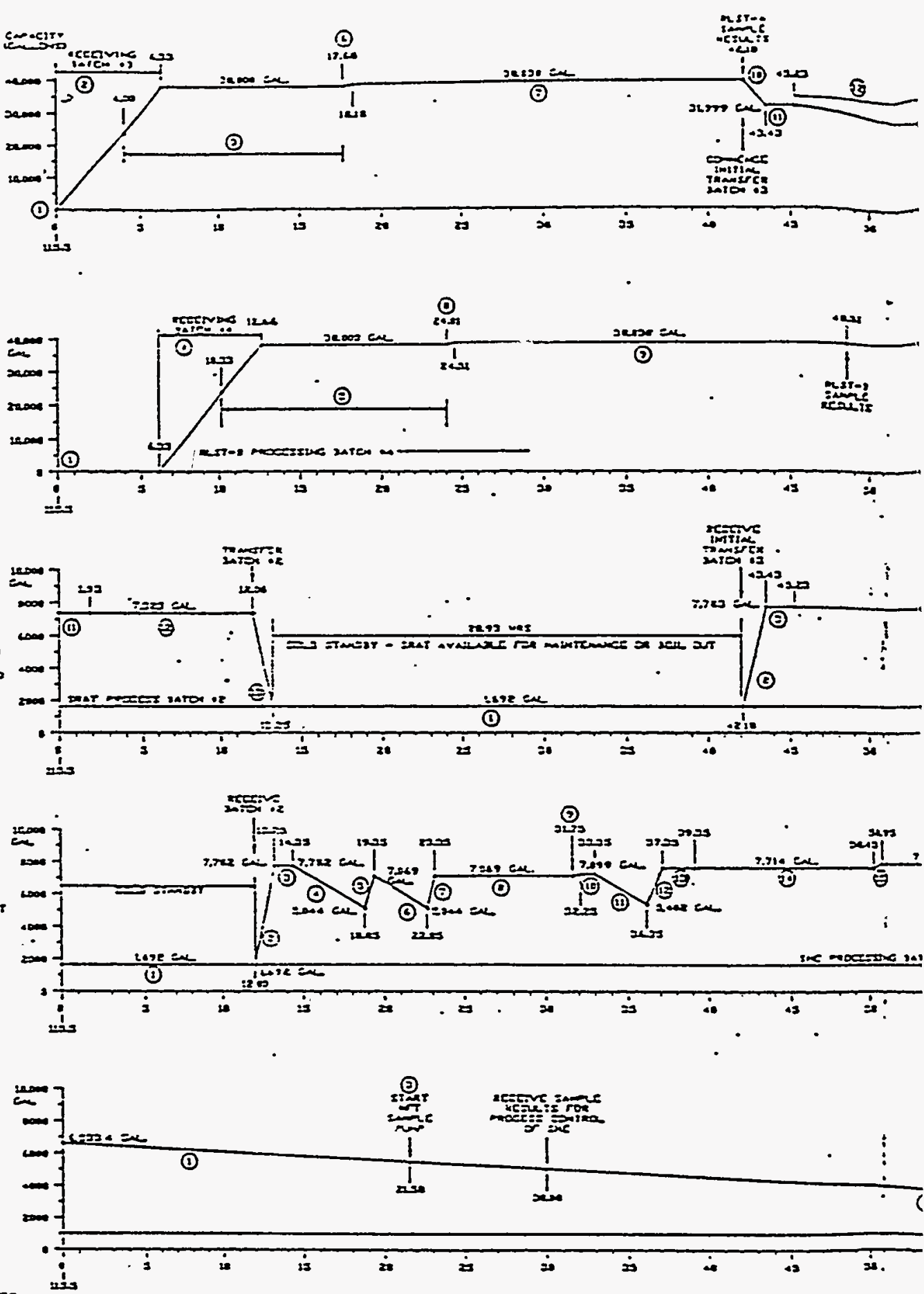

EEmeanal otrs.

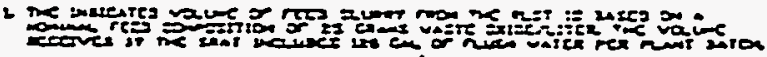

2 rencestor Puce

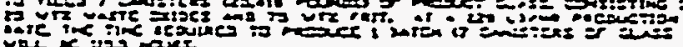

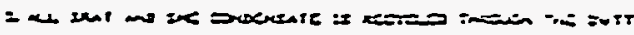

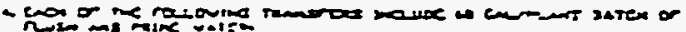

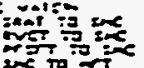

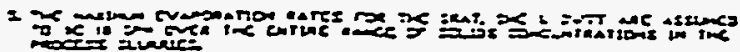

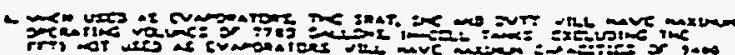

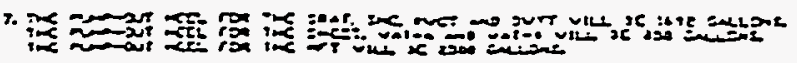

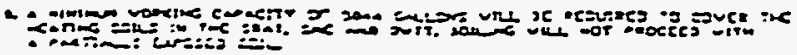

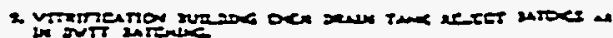

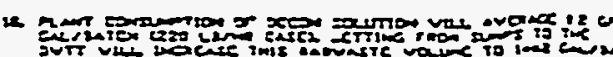

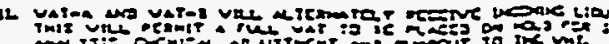

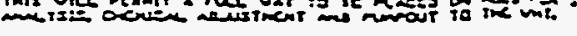

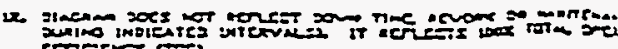

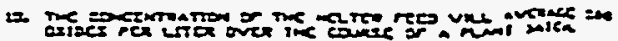

14 :

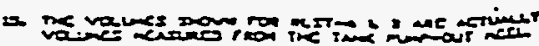

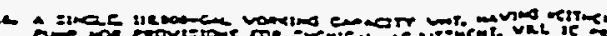

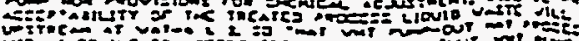

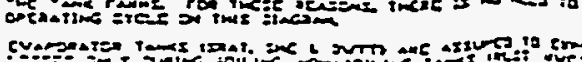

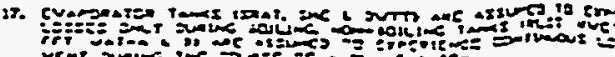
作 


\section{APPENDIX B}

\section{APPLICABLE GERMAN VITRIFICATION TECHNOLOGY STATUS}




\title{
FOREIGN TRAVEL REPORT
}

\author{
KARISRUHE, GERMANY
}

MI, Elliont

G^ Jensen

July 1993

Pacific Northwest Laboratory

Richland, Washingion

B. 1 
analyses of samples from the Researcn-Scale Melter (RSMi) at PNL. Some of the $\mathrm{RuO}_{2}$ cn'stals analyzed by SEM/EDX also had a $\mathrm{Rh}$ peak, indicating a mixture of $\mathrm{Rh}_{x} \mathrm{O}_{y}$ and $\mathrm{RuO}_{2}$.

The next topic covered was the formation of platinum metal alloys and oxides with increasing temperature. Prof. Pentinghaus predicted that ruthenium oxidized to $\mathrm{RuO}_{2}$ at $500^{\circ} \mathrm{C}$, rhodium oxidizes to $\mathrm{Rh}_{2} \mathrm{O}_{3}$ at $550^{\circ} \mathrm{C}$, and palladium metal and tellurium metal alloy at $800^{\circ} \mathrm{C}$. He also predicted that ruthenium and rhodium oxides combine at approximately $1000^{\circ} \mathrm{C}$ and rhodium metal alloys with the palladium/tellurium alloy at $1000^{\circ} \mathrm{C}$.

KFK tried to predict the oxidation state by ${ }^{57} \mathrm{Fe}$ Mössbauer spectrum. The results indicated that most of the iron in the glass was in the $\mathrm{Fe}^{+3}$ state. It was unclear if this can be quantified.

\section{June 17 - Further Review of Draft ESM Report}

On the morning of June 17, Mr. Elliott, Dr. Roth, and Mr. Grünewald finished the review of the suggested changes made to the document by Mr. Elliott. These were only general changes to the text. The more specific changes were not planned until the next day. Many of the changes were re-edited with suggestions made by Mr. Grünewald and Dr. Roth.

\section{QA Review by Dr. Jensen}

Dr. Jensen completed a cuulity assurance surveillance of the records of Mr. Grünewald. Everything was found to be acceptable and the QA form sent by B.D. Slonecker of PNL was completed. This form is shown in Appendix D.

\section{Tour of V.W1}

On June 17, Dr. Roth and Mr. Karlheinz Weiß gave Mr. Elliott and Dr. Jensen a tour of the V-W1 vitrification facility. This is a hot cell mock-up where testing is being done for the Chinese. KfK and several other companies are transferring LFCM technology to China as part of a joint project started in $1991^{3}$. The first step of the project is the completion of a full-scale mock-up vitrification facility in China in 1994. This mock-up, the VPM (Vitrification Plant Mock-up), is scheduled for operation in

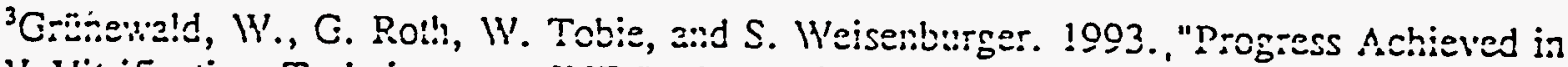
HLW Vitrification Techniques at INE." Paper in preparation for the 1993 International Conference on Nuclear Waste Managenent and Environmcnial Remediation, Prague, Czechosiovàiva.
} 
1995. The melter for this inock-up was designed and built at KfK. It is being tested in V-W1 before being shipped to China. The melter is an enlarged version of the K-6' melter. It has a glass surface area of $1.4 \mathrm{~m}^{2}$ and a design feed rate of $65 \mathrm{~L} / \mathrm{h}$. This corresponds to a glass production rate of $38.4 \mathrm{~kg} / \mathrm{hr}$. As in the $\mathrm{K}-\mathrm{\sigma}^{\prime}$ meltcr, the frit beads (1-2 mm diameter) are discontinuously added to the melter through a separate line. The beads are fed in three batches of $3.75 \mathrm{~kg}$ for each airlift batch of simulant. The beads are metered using a strain gauge and hopper system. The feed line from the hopper to the-melter is approximately $60^{\circ}$ to the horizontal. Although the Chinese HLW does not contain high concentrations of noble metals, the melter is designed for concentrations of noble metals in the glass up to 1 wi\%.

The feed and off gas systems in V-W1 are very similar to the VA-WAK except all of the piping is put through remote penetrations into the hot cell mock-up. The mockup has full remote crane and manipulator access and gond viewing windows. The conirol system for this melter is new. Dr. Roth designed a Windows ${ }^{\text {TM }}$ based data acquisition system that is much different than those previously used at INE.

The first run on the Chinese melter in V-W1 ran for approximately four weeks. The system worked well. The feed nozzle had been removed after the run and had very little feed splattered on it. The bottom drain operated fine. It has a two zone induction coil, but they only use the top and bottom taps. The first time that they use it they need to heat it up for one to two hours before pouring. After the first pour, they leave it idling at a low power (just enough to stop it). The off gas line from the melter is kept clean with Blasters similar to those used on the ESM. The blusters are essentially air cănnons and they tested them using both 4 bar $(58 \mathrm{psi})$ and 7 bar (102 psi) air pressure. The pipes started to become fouled using only 4 bars of pressure so they switched back to the 7 bar air.

As an interesting note, $\mathrm{KfK}$ is now ordering their frit beads from a source in China. They previously ordered it from a European supplier but found the Chinese supplier to be cheaper and the frit was of a higher quality.

\section{June 18 - Final Review of Document}

On the last day of the PNL visit, Mr. Elliott and Dr. Jensen met with Mr. Grünewald for a detailed review of the draft ESM report. Mr. Elliott gave Mr. Grünewald an electronic copy of the edited document with all of the comments made by reviews as well as changes made during the $\mathrm{KfK}$ visit.

A final review of the document was done by going over each reviewer's comments individually. Approximately one half of the comments could be skipped because they had already been mentioned in previous meetings. Some were reviewed again to stress the importance of the specific comments. Individual comments were made by $D$ on 
APPENDIX C

CALCULATIONS 
Option: Increase SRAT/SME/DWTT WeatinglEooling Heal Trans fer A:2a By Converting Coil To Heating Coil And Installing Cooling Jacket $Q$ in Tank Res: "D.E.Larsoy, February 1989, HWVP-89-1VJ0010100A,Pg $2-31$

Curreut heat trans jiur arear: SRAT/SME Heating: 340 fth
$C=0 l i n=$

Revisided heat transfer area : SRATISME - Malle cooling coil heating coil

- Install a 7 -ft high eooling jaclect on Tonk: $T D L=3.14(125+) 75 t: 264 \mathrm{ft}=$

Ratio of revised to reference beat trang bers arews

$$
\begin{aligned}
& \text { Hecting: } \frac{140+340}{340}=1.4 \\
& \text { cosling } \frac{264}{140}=1.9
\end{aligned}
$$

Asswme (they Checi) : Sirvices can provite $40 \% 0$ more 5 team and $90 \% 10$ merf $=001$ ing weter to teinle sow hiatingl cooling service, Associcter of condinsirub can be modis ied to provide. $\rightarrow 00 / 0$ mere cooling =apacity by in $=$ reasing wagth, nimmburs of twbes,

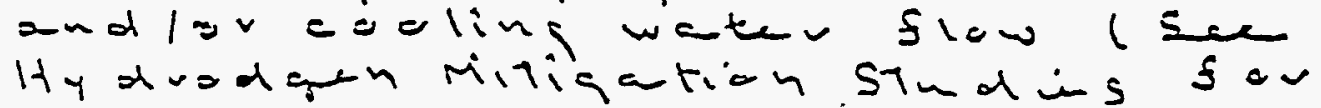

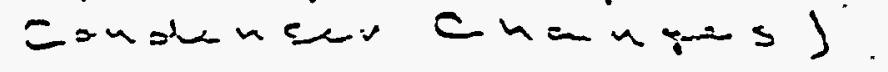

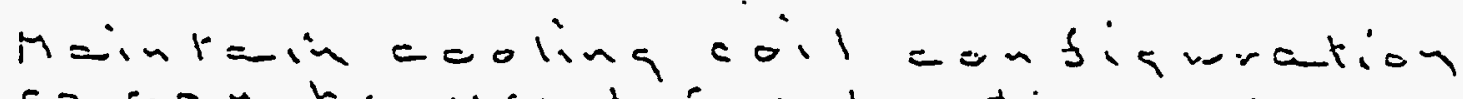

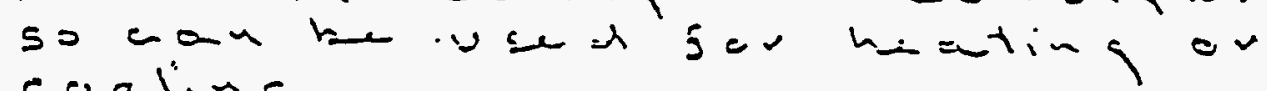
coolins

C. 1 


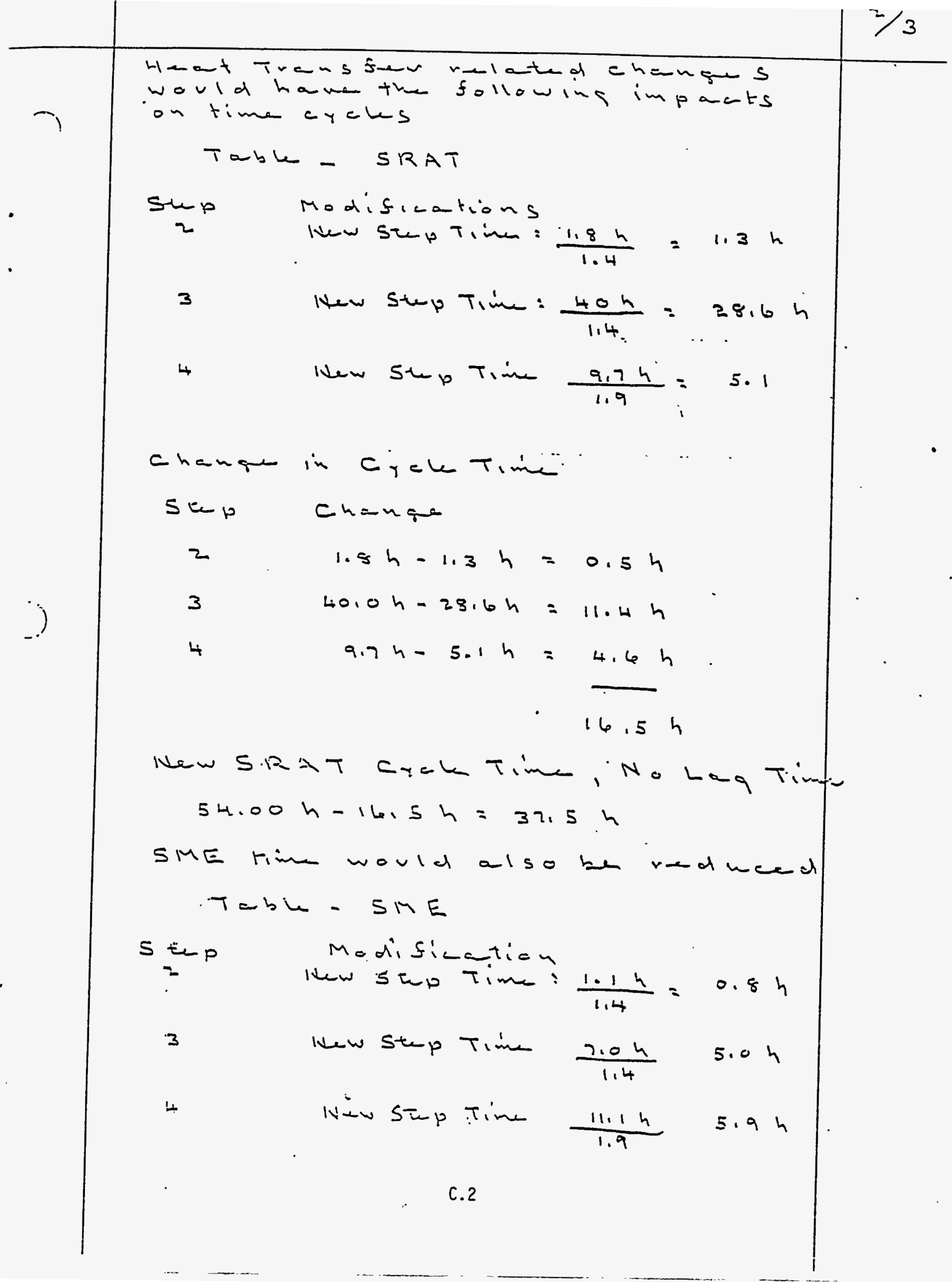




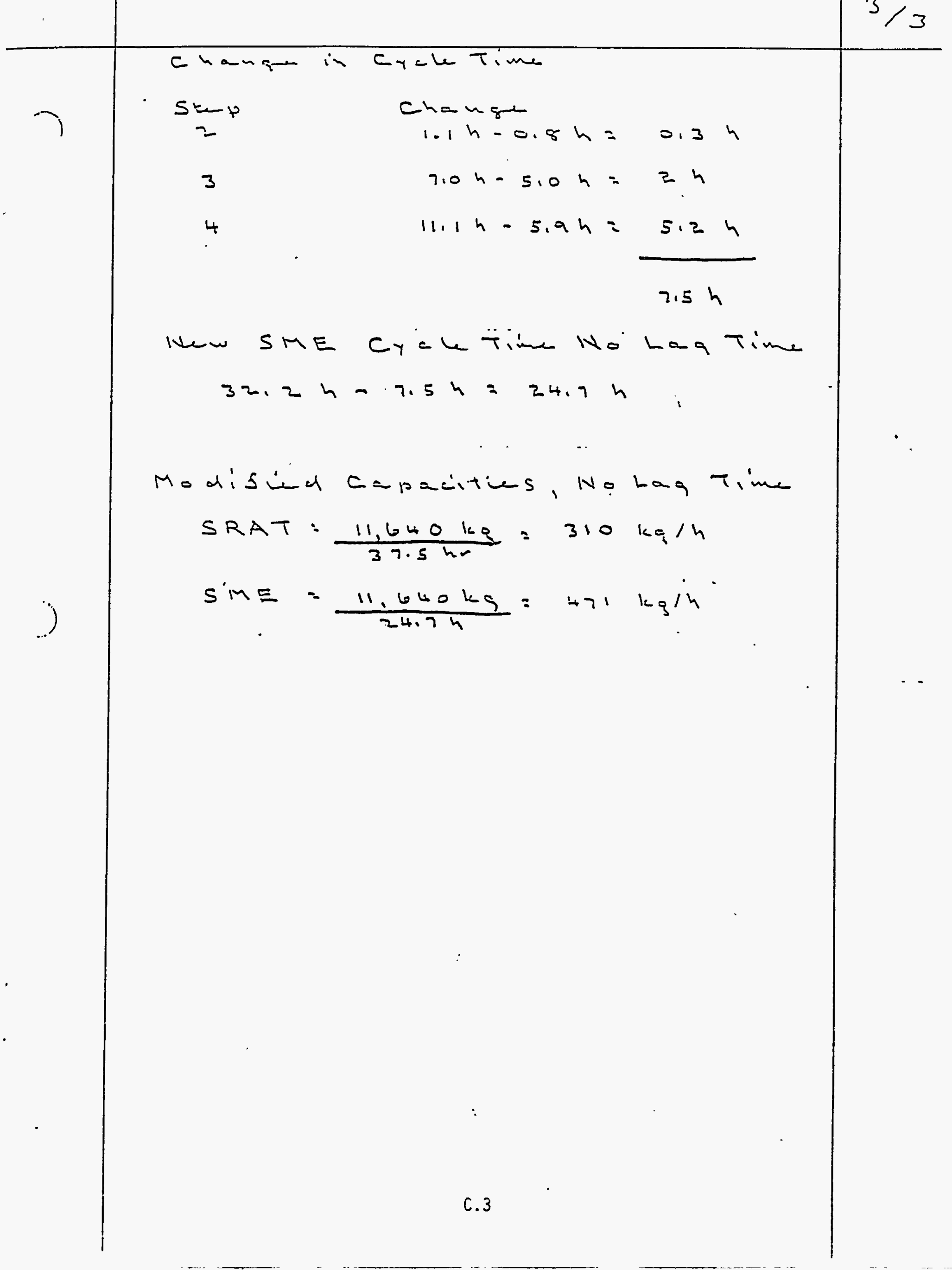


$41 L_{x} 019 \approx 4 / 57219=$

$\cdots \quad \cdots 9 \cdot 92$

(om rb521/OMrb54)(4/703911)

$m=1$ bnissond 55019

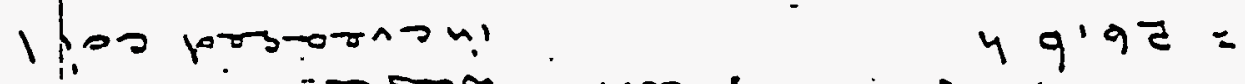
Kq prinnigin

- on on

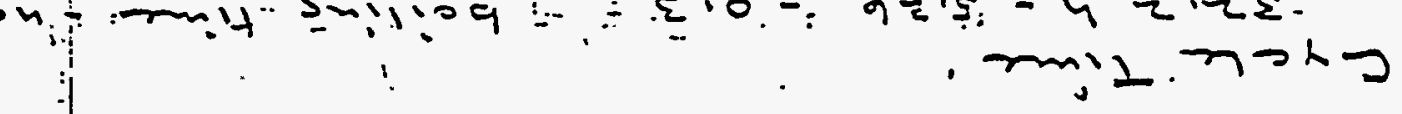

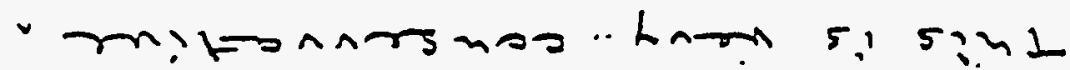

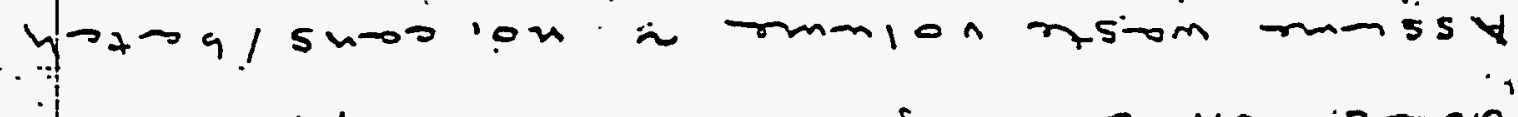

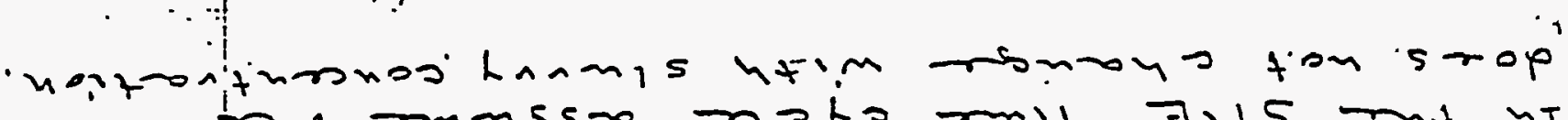

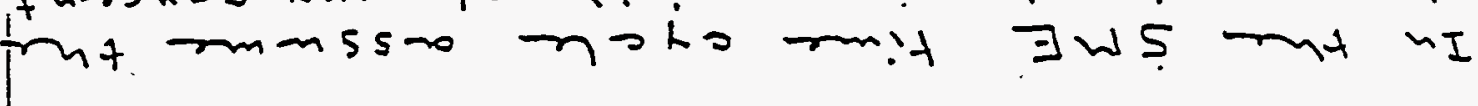

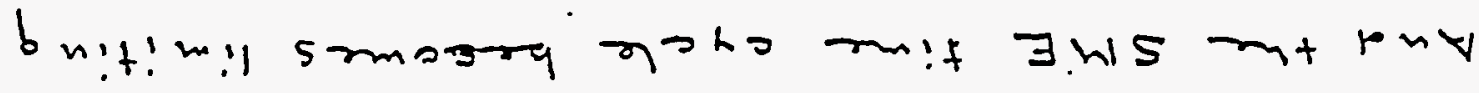

$4+1=(100049+7-)+\left(1445.0^{\circ}\right)+(41.5+404-)+4 \pi 5$

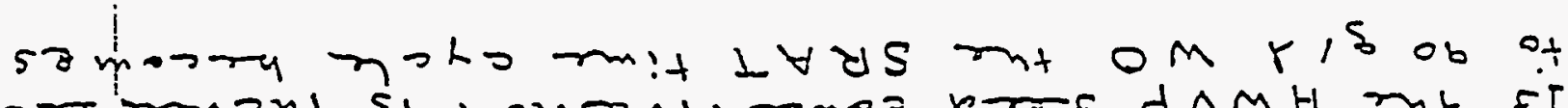

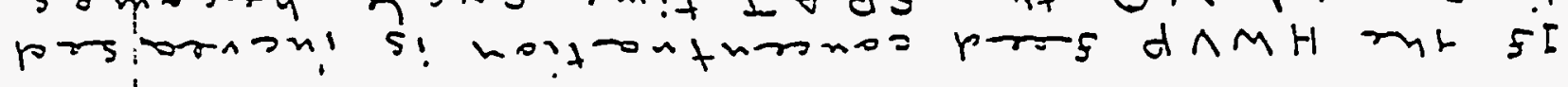

